AGRO EKONOMI, Vol 29, Issue 2, December 2018, Page. 274-286

DOI : http://doi.org/10.22146/ae.35979

ISSN 0215-8787 (print), ISSN 2541-1616 (online)

Available at https://jurnal.ugm.ac.id/jae/

\title{
FINANCIAL FEASIBILITY \\ OF THE VANAME SHRIMP FARMING BUSINESS IN THE PURWOREJO REGENCY
}

\section{Kelayakan Finansial Usaha Budidaya Udang Vaname di Kabupaten Purworejo}

\author{
Putri Makalingga $^{1}$, Any Suryantini ${ }^{2}$, Lestari Rahayu Waluyati ${ }^{3}$ \\ ${ }^{1}$ Master Students of Agribusiness Management, Faculty of Agriculture, \\ Universitas Gadjah Mada \\ ${ }^{2,3}$ Faculty of Agriculture, Universitas Gadjah Mada \\ Jl. Flora No. 1 Bulaksumur, 55281 Yogyakarta, Telp. (0274) 555675 \\ putrimakalingga10@gmail.com
}

Submitted: 15 August 2018; Revised: 18 October 2018; Accepted: 22 November 2018

\begin{abstract}
The study aims to determine the financial feasibility of vaname shrimp farming business in the Purworejo Regency. Descriptive approach was used as the method of analysis. The data analyzed were primary and secondary data. The research site was determined purposively (i.e., via purposive sampling) in the Purworejo District by considering the vaname shrimp cultivation there. The analysis used the financial feasibility analysis, Net Present Value (NPV), Internal Rate of Return (IRR), and Net Benefit/Cost Ratio (Net B/C Ratio). The result concerning financial feasibility was obtained from the earnings of vaname shrimp farming business amounting to $1,415,992,500$ IDR (Rp 1,415,992,500, with IDR or Rp referring to Indonesian rupiah as USD is to US dollar) with the total cost incurred in one year of production estimated to be $364,207,148$ IDR, a revenue of 1,051,785,352 IDR, a profit of 999,196,084 IDR, an NPV (NPV $>1$ as criterion) of 2,539,407,216 IDR, an IRR (IRR $>$ interest rate of $7.6 \%$ as criterion) of $98 \%$, and a Net $\mathrm{B} / \mathrm{C}$ Ratio (net $\mathrm{B} / \mathrm{C}$ ratio $>1$ as criterion) of 2.01. Thus, from the results of financial feasibility analysis, it could be concluded that the business of vaname shrimp farming in the Purworejo Regency is feasible to run. It is suggested that workforce training and guidance are important to develop in order to improve the competitiveness of the farmers. Farmers should know about how to cultivate fish to produce high quality of fishery products and become responsible farmers.
\end{abstract}

Keywords: Financial Feasibility, Net Present Value, Vaname Shrimp

Makalingga, P., Suryantini, A., \& Waluyati, L.R. (2018) Financial Feasibility of The Vaname Shrimp Farming Business in The Purworejo Regency. Agro Ekonomi, 29(2) : 274-286

\section{INTISARI}

Penelitian ini bertujuan untuk mengetahui kelayakan finanasial usaha budidaya udang vaname di Kabupaten Purworejo. Metode yang digunakan adalah deskriptif analisis. Data yang dianalisis adalah data primer dan data sekunder. Pemilihan lokasi ditentukan secara sengaja (purposive sampling) di Kabupaten Purworejo dengan pertimbangan melakukan 
usaha budidaya udang vaname. Analisis yang digunakan: analisis kelayakan finansial, Net Present Value (NPV), Internal Rate of Return (IRR), Net Benefit Cost Ratio (Net B/C Ratio). Hasil kelayakan finansial diperoleh dari penerimaan usaha budidaya udang vaname sebesar $R p$ 1.415.992.500 dengan total biaya yang dikeluarkan dalam satu tahun produksi diperkirakan sebesar $R p$ 364.207.148, pendapatan sebesar $R p$ 1.051.785.352, keuntungannya sebesar Rp 999.196.084, nilai Net Present Value (NPV>1) sebesar Rp 2.539.407.216, nilai Internal Rate of Return (IRR $>$ suku bunga 7,6\%) sebesar 98\%, nilai Net Benefit Cost Ratio (net B/C ratio >1) sebesar 2,01. Dengan demikian dari hasil analisis kelayakan finansial dapat disimpulkan bahwa usaha budidaya udang vaname di Kabupaten Purworejo layak untuk dijalankan. Berdasarkan penelitian yang telah dilakukan, maka saran yang dapat diberikan untuk kegiatan usaha budidaya udang vaname adalah: Pelatihan dan pembinaan untuk tenaga kerja guna meningkatkan daya saing pembudidaya. Petambak harus mengetahui tentang bagaimana cara budidaya ikan yang baik (CBIB) dengan tujuan sebagai jaminan mutu produk perikanan dan menjadi pembudidaya yang bertanggung jawab.

Kata kunci: Kelayakan Finansial, Udang Vaname

\section{INTRODUCTION}

The rapid development of aquaculture activities with the application of intensive systems has led to the problem of decreasing in power to support shrimp life in shrimp farming. A further resulting impact has been the occurrence of a series of attacks by diseases causing major losses. The use of intensive cultivation systems is likely to increase the incidence of disease so that to cope with it, drugs and chemicals need to be used. Currently, fishery products for export should meet the requirements for food safety (such as being free of any antibiotic and its derivatives and heavy metals) as well as for sanitation and hygiene. In the course of attaining the national target of fishery development, efforts need to be made to develop the fishery business.

Shrimp cultivation technology has also undergone a rapid development from the traditional maintenance relying only on the supply of small and young shrimp (or shrimp fry) from nature at high tide into the intensive technology requiring the provision of shrimp fry, water management, and food in a planned manner (Reksono et al., 2012). In addition, maintenance of storage ponds should also be maintained to minimize disease during the cultivation period. Water taken for cultivation must be properly filtered and disinfected after the disease is found in the aquaculture pond (Srinivas et al., 2016).

Fishery is a sector of excellence in Indonesia in the export sector. One of the leading products for export in the fishery sector is shrimp. Vaname shrimp holds a highly potential market prospect especially for export. The production of shrimp in Indonesia is developed from the shrimp caught at sea and shrimp yielded in cultivation. In terms of development, the production of shrimp caught at sea 
has undergone rises and falls while the production of shrimp in cultivation has undergone significant fluctuations (Mohani et al., 2016).

As production increases in the fishery sector, demand for fresh shrimp also increases. Therefore, the shrimp caught would be handled as well as possible in order to keep it fresh up to the moment it reaches the hands of consumers but not a few shrimp, either, are wrongly handled so that they undergo a lowering of quality. The selling price becomes increasingly lower so that the fishermen do not obtain the profit that they should get. A lowering in the selling price of shrimp could also be caused by disease and might be overcome by encouraging the cultivation of vaname shrimp in freshwater as they are then proven to be more resistant to disease (Geffken et al., 2017).

There are several things to consider in what to select for cultivation in freshwater, namely, the condition parameters of the water for cultivation and financial analysis factors. For water suitability, aquaculture farmers should measure the conditions of the water and, for financial analysis, they should collect data of the cost incurred and the revenue earned in doing business. Financial analysis is used because investment valuation factors in financial analysis could provide the considerations needed by the farmers in the cultivation business such as the profit or loss, the long process of payback, and the business that is still safe to do although not profitable (Lumentut \& Hartati, 2015).

Vaname shrimp (Litopenaeus vannamei) is a commodity that is quite popular among the farmers concerned. The presence of the vaname shrimp variety is expected not only to increase the number of choices for the farmers but also to support the rise of shrimp farming business in Indonesia. But on the other hand the problem in vaname shrimp cultivation with high stocking density decreased oxygen by $2.8 \mathrm{ppm}$ at night. This is caused by metabolic processes and respiration at night which cause dissolved oxygen deficiency (Susilowati et al., 2014). To sufficiently take advantage of it requires shrimp maintenance efforts to produce large-sized vaname shrimp, namely, those of size 40-50 (Amri \& Kanna, 2008). Vaname shrimp has the right advantages for freshwater shrimp farming activities: they are responsive to feed/high in appetite, more resistant to disease and poor environmental quality, faster in growth, high in survival rate, sufficiently high in stocking density, and relatively short in maintenance time, which is about 90-100 days per cycle (Purnamasari et al., 2017).

The potential of fisheries in the Purworejo Regency is actually quite great. But unfortunately the fate of the fishermen and shrimp farmers is still quite a matter of apprehension because they are still at the middle- and lower-class levels in living 
condition. Breakthroughs are required to maximize the potential for welfare (Biantara et al., 2016).

In this study, the focus of the discussion is only on the analysis of financial feasibility in maximizing farming business in support of a financial benefit for the shrimp farmers. The study is expected to aid the farmers' business plan as well as to provide input for the local government in taking appropriate policies for the development of farming business (Ely \& Darwanto, 2014).

Based on the discussion as above, the study aims to investigate the financial feasibility of shrimp farming business in the Purworejo Regency.

\section{METHODS}

The basic method used in the research was the descriptive method of analysis (Saputri, 2017). The research site selection was conducted by means of purposive sampling; it was based on the consideration that the Purworejo Regency, as previously mentioned, was one of the regencies that managed to win in the Fish and Shrimp Cultivation Contest at the Central Java Level in 2015.

The research respondents were selected with the research objective as basis. The purpose of the research was to analyze the financial feasibility of shrimp farming business. The selection of respondents was conducted by means of accidental sampling resulting with 51 respondents, taking into account that the respondents knew the condition of shrimp farming business in the Purworejo Regency. This research lasted from October to December in 2017 and used primary data and secondary data. The collected data were then tabulated and analyzed by using the following steps.

\section{Financial Feasibility Analysis}

At this stage, cost and benefit components were used to facilitate the grouping of both sections. The investment criteria was used to determine the level of business feasibility quantitatively. The cost components incurred includes investment costs, fixed costs, and operating costs. The benefits of vaname shrimp farming business were all conditions encouraging the attainment of the business goal, namely, to gain profit.

\section{Net Present Value (NPV)}

The net present value (NPV) could be interpreted as the present value of the income stream generated by investment. NPV is the result of a deduction from income at a discounted cost. Mathematically, the calculation of NPV could be formulated as follows:

$$
\mathrm{NPV}=\sum_{t=0}^{n} \frac{\mathrm{Bt}-\mathrm{Ct}}{(1+\mathrm{i})^{2}}
$$


where

$\mathrm{NPV}=$ net present value (in IDR, i.e., Indonesian rupiah or $\mathrm{Rp}$ )

$\mathrm{Bt}=$ benefit or benefit in year $\mathrm{t}$

$\mathrm{Ct}=$ cost or cost in year $\mathrm{t}$

$\mathrm{i}=$ interest rate used

$\mathrm{t}=$ year $\mathrm{t}$

The feasibility indicator was as follows. If the NPV was positive (NPV $>0$ ), then the business was feasible to run. Conversely, if the NPV was negative $(\mathrm{NPV}<0)$, then the business was not feasible to run.

\section{Internal Rate of Return (IRR)}

The internal rate of return (IRR) was the value of the interest rate $i$ that made the NPV of the project equal to zero. IRR could be defined as the interest rate at which the present value and total cost are equal to the present value of total revenue. IRR is also considered a net return on investment, where positive net benefits are reinvested in the same subsequent year and are given interest for the remainder of the project life. IRR could be formulated as follows:

$$
\mathrm{IRR}=\mathrm{i}_{1}+\frac{\mathrm{NPV}_{1}}{\mathrm{NPV}_{1}-\mathrm{NPV}_{2}}\left(\mathrm{i}_{2}-\mathrm{i}_{1}\right)
$$

where

$\mathrm{NPV}_{1}=\mathrm{NPV}$ which is still positive

$\mathrm{NPV}_{2}=\mathrm{NPV}$ which is already negative

$\mathrm{i}_{1} \quad=$ discount rate which still gives positive NPV $\mathrm{i}_{2}=$ discount rate which already gives negative NPV

The criterion was as follows. If the IRR $>$ interest rate applied, then the project was declared feasible. If the IRR $<$ interest rate applied, then the project was declared unfeasible.

\section{Net Benefit/Cost Ratio (Net B/C Ratio)}

Net B/C Ratio is the ratio of the number of positive present values with that of the negative present values. In general, these criteria are calculated by means of the formula:

$\operatorname{Net} \frac{B}{C}=\frac{\sum_{t=0}^{t=5} \frac{(B t-C t)}{(1+i)^{t}}}{\sum_{t=0}^{t=5} \frac{(C t-B t)}{(1+i)^{t}}}=\frac{(B t-C t)>0}{(B t-C t)<0}$

where

$\mathrm{Bt}=$ gross benefit caused by investment in year $\mathrm{t}$

$\mathrm{Ct}=$ gross cost caused by investment in year $\mathrm{t}$

i $=$ interest rate

$\mathrm{t}=$ project life $0,1,2,3,4,5$

The criterion used was as follows. If the Net B/C Ratio $>1$, then the business was feasible. Furthermore, if the Net B/C Ratio $<1$, then the business was not feasible.

\section{Sensitivity Analysis}

The sensitivity analysis needed to be done because, in the investment activity, the calculation was based on projects that contained uncertainty about what would 
happen in the future. The sensitivity analysis sought several replacement values on the component costs and benefits that occurred, which still met the minimum criteria of investment feasibility or still got a normal profit. The normal gain occurred when the $\mathrm{NPV}$ value was equal to zero (NPV=0). An NPV equal to 0 would make the IRR equal to the interest rate and $\mathrm{Net} \mathrm{B} / \mathrm{C}$ equal to 1 (cateris paribus). What is referred to is to what extent the business would tolerate increase in price or decrease in input and decrease in price or increase in output.

\section{RESULTS AND DISCUSSION}

The sample farmers who were the respondents in the study concerned here were shrimp farmers in the Ketawangrejo Village, the Patutrejo Village, the Harjobinangun Village, the Munggangsari Village, and the Kertojayan Village. The sample identity of the respondents in this study was based on interviews with 51 shrimp farmer respondents. The data were obtained by observation and interview means using questionnaires.

This research explain vaname shrimp is a prima donna fishery commodity and is very promising because of the high demand from various countries in the world, and until now vaname shrimp export opportunities to the international market are still very wide open, certainly very profitable if doing business and investing in this sector.

\section{Financial Feasibility Analysis}

Based on the analysis on vaname shrimp farming business in the Purworejo Regency, the following could be known.

\section{Investment Cost}

The investment cost was the fixed cost needed to run the vaname shrimp farming business; the value of the cost was not influenced by the amount of production. The depreciation cost of shrimp farming business was determined from facilities and infrastructure (including equipment) used for shrimp farming activities. The amount of investment cost needed in the 0th year for pond extension range of 1000-1500 $\mathrm{m}^{2}$ was $1,033,420,165$ IDR.

Depreciation is the cost charged to fixed assets so that it can be utilized when the fixed assets are not reusable. The depreciaton value and tools required in the 0 year for a pond within $1000-1500$ $\mathrm{m}^{2}$ of area range is $12,971,014 \mathrm{IDR}$. The higest shrinkage in vaname shrimp farming in Purworejo District is plastic mulch. In average Purworejo plastic mulch is often damaged, like torn. Plastic mulch functions as a cover for the edge of the pond. To find out the highest total depreciation value or not, at the time of research and after interviewing Purworejo farmers, the average farmer answers that all depends on the dollar price and current market price. If the price of production equipment and other equipment changes every year, then 
Table 1. Recapitulation of Investment Costs, Depreciation Costs, and Residual Values of the Vaname Shrimp Pond Farming Business

\begin{tabular}{lrrrrr}
\hline Cost Component & $\begin{array}{r}\text { Amount of } \\
\text { Investment }\end{array}$ & \multicolumn{1}{c}{$\begin{array}{c}\text { Residual } \\
\text { Value }\end{array}$} & $\begin{array}{c}\text { Economic } \\
\text { Age }\end{array}$ & $\begin{array}{c}\text { Depreciation } \\
\text { Value } \\
\text { in 1 Year }\end{array}$ & $\begin{array}{c}\text { Depreciation } \\
\text { Value } \\
\text { in 1 Cycle }\end{array}$ \\
\hline Land & $992,575,107$ & & & & \\
Building & $9,843,137$ & $1,705,579$ & 5 & $1,627,512$ & 542,504 \\
Production Tools & & & & & \\
a. Water Pump & $2,588,235$ & 364,706 & 1 & $2,223,529$ & 741,176 \\
b. Water Wheel & 872,059 & 105,686 & 5 & 153,275 & 51,092 \\
c. Siphon Pipe & 224,902 & 38,824 & 5 & 37,216 & 12,405 \\
d. Waste Pipe & 209,608 & 35,294 & 5 & 34,863 & 11,621 \\
e. Spiral Pipe & $4,878,431$ & 436,863 & 5 & 888,314 & 296,105 \\
f. Mulch Plastic & $3,422,549$ & 246,765 & 1 & $3,175,784$ & $1,058,595$ \\
g. Axle & $5,803,922$ & 676,471 & 5 & $1,025,490$ & 341,830 \\
h. Diesel Genset & $5,356,863$ & 694,118 & 4 & $1,165,686$ & 388,562 \\
i. Anco Wiper & 236,176 & 10,706 & 4 & 56,368 & 18,789 \\
j. Fishnet & 693,137 & 35,980 & 3 & 219,052 & 73,017 \\
k. Refractometer & $3,401,961$ & 320,980 & 3 & $1,026,994$ & 342,331 \\
l. pH Meter & $2,500,118$ & 221,569 & 2 & $1,139,275$ & 379,758 \\
m. Lighting & 96,098 & 9,431 & 1 & 86,667 & 28,889 \\
Other Equipment & & & & & \\
a. Digital Scales & 283,137 & 46,471 & 5 & 47,333 & 15,778 \\
b. Jerrycans & 48,059 & 6,394 & 5 & 8,333 & 2,778 \\
c. Drum & 305,882 & 101,961 & 5 & 40,784 & 13,595 \\
d. Hoe & 80,784 & 8,078 & 5 & 14,541 & 4,847 \\
\hline \multicolumn{1}{c}{ Total } & $\mathbf{1 , 0 3 3 , 4 2 0 , 1 6 5}$ & $\mathbf{5 , 0 6 5 , 8 7 6}$ & & $\mathbf{1 2 , 9 7 1 , 0 1 4}$ & $\mathbf{4 , 3 2 3 , 6 7 1}$ \\
\hline Source: Primaty & & & & &
\end{tabular}

Source: Primary Data, 2017

the total value shrinkage also changes. The following is a breakdown and tools of the invesment cost and the depreciation value incurred for the pond ranging within 1000$1500 \mathrm{~m}^{2}$ in area listed in table 1.

Table 1. shows that the biggest component of investment cost in the vaname shrimp farming in Purworejo District consisted of the axle and the diesel genset. The axle/rotation tool here was a tool to combine some waterwheel blades (or paddles) in movement, with one axle usually with six waterwheel blades. In one plot of pond, there are three to four axles. Then the use of the diesel genset in shrimp farming activities is aimed to save electricity usage so that energy costs (electricity bill costs) can be minimized. Generally, one plot of pond had more than one diesel genset. The diesel genset was needed to move the axle and waterwheel in shrimp farming.

\section{Operating Costs}

An operating (or operational) cost is a fixed cost whose value is influenced by 
the amount of output produced. The more the output that is produced, the greater the operational costs that are required. The components of operational costs in the vaname shrimp farming business in Purworejo Regency include shrimp fry, feed, probiotics, fertilizer, lime, labor, oil, diesel genset, electricity, harvest cost, bonus, tool repair, thanksgiving feast, and land tax. The point of fries are shrimp seeds which are naturally captured or mainteined by shrimp hatcheries starting from naupli stage to PL (Post Larvae). Probiotics are benefical decomposers of dissolved organic matter and can fertilize the water. Also, they can be mixed through feed and stocked directly to nourish shrimp intestines. Fertilizer is functioned to grow plankton or provide food needed by microorganisms. Its use in ponds in Purworejo is mostly those which do not use fertilizer. Lime is functioned to neutralize $\mathrm{pH}$, reduce plankton at night applications, grow in the morning application and add minerals. In Purworejo, the use of lime is usually during the rainy season only. Oil as a diesel lubricant for the movement of waterwheels. Diesel as diesel fuel is used to move the windmill. In Purworejo the use of diesel fuel is more intense than oil. Electricity is operated for lighting at night. The farm's allocation of use is $0.5 \%$ of taxable sale value. The average operational cost required for vaname shrimp farming business with an area in the range of 1000-
$1500 \mathrm{~m}^{2}$ is $121,402,383$ IDR per cycle. Operational cost in the next harvest season were assumed to increase by $5 \%$ according to the current inflation rate, with the production capacity assumed to increase by $5 \%$, resulting in an annual operating cost of 364,207,148 IDR, assuming a year contains three production processes. Here is the composition of variable cost and fixed cost of shrimp in the Purworejo Regency per year.

Table 2. shows that the biggest operational cost component in vaname shrimp farming in the Purworejo Regency is feed. The need of feed absolutely relied on factory-made feed, because such feed is more assured in quality and complete nutritional content. Feeding is done from the time shrimp is stocked. As for the given dose, shrimp aged 1-15 days are fed as often as three times a day and those with age of $>15$ days are fed four times a day until harvest time. The average pond farmers in Purworejo for one production process could spend around 2-3 tons of feed according to the number of shrimp stocked in the range of 100,000 to 150,000 heads per plot with feed prices ranging from 365,000 to 480,000 .

\section{Analysis of Revenue in Vaname Shrimp Farming}

The farmers in the study sites conduct a total harvesting system, i.e., harvesting only once in each maintenance process. 
Table 2. Recapitulation of Operational Costs (Variable Costs and Fixed Costs) of Vaname Shrimp Pond Farming Business

\begin{tabular}{|c|c|c|}
\hline $\begin{array}{c}\text { Variable Cost } \\
\text { Structure }\end{array}$ & $\begin{array}{c}\text { Total Cost } \\
1 \text { Year }\end{array}$ & $\begin{array}{l}\text { Total Cost } \\
1 \text { Cycle }\end{array}$ \\
\hline Shrimp Fry & $19,857,707$ & $6,619,236$ \\
\hline \multicolumn{3}{|l|}{ Adjuvant } \\
\hline a. Feed & $130,701,000$ & $43,567,000$ \\
\hline b. Probiotics & $3,177,515$ & $1,059,172$ \\
\hline c. Fertilizer & $2,276,515$ & 758,838 \\
\hline d. Chalk & $32,751,700$ & $10,917,233$ \\
\hline Labor & $31,777,451$ & $10,592,484$ \\
\hline Oil & $8,432,353$ & $2,810,784$ \\
\hline Diesel Fuel & $70,183,000$ & $23,394,333$ \\
\hline Electricity & $26,078,431$ & $8,692,810$ \\
\hline Harvesting Cost & $12,894,118$ & $4,298,039$ \\
\hline Bonus & $6,557,800$ & $2,185,933$ \\
\hline Total & $344,687,590$ & $114,895,863$ \\
\hline Fixed Cost Details & Total Cost in 1 Year & Total Cost in 1 Cycle \\
\hline Cost of Depreciation & $12,971,014$ & $4,323,671$ \\
\hline Other Costs & $6,548,544$ & $2,182,848$ \\
\hline a. Tool Repair & $5,192,006$ & $1,730,669$ \\
\hline b. Thanksgiving Feast & 516,667 & 172,222 \\
\hline c. Land Tax & 839,871 & 279,957 \\
\hline Total & $19,519,558$ & $6,506,519$ \\
\hline
\end{tabular}

Source: Primary Data, 2017

On the average, in one period the farmers harvested three times. A pond with an area within the range of 1000-1500 $\mathrm{m}^{2}$ could produce shrimp with a total weight of as much as $9,165 \mathrm{~kg} /$ cycle or about 27,495 $\mathrm{kg} /$ year, with the average shrimp size of 70. The average price of shrimp in the research is calculated to be $\mathrm{Rp} 51,500 /$ $\mathrm{kg}$, which is obtained from the average prices of various vaname shrimp sizes harvested. The amount of total revenue of farmers in one period is $1,415,992,500$ IDR. The higher the selling price and the production of the shrimp, the greater the revenue obtained by the farmers, and vice versa. When the harvest arrives, collectors or middlemen go directly to the location of the farm belonging to the farmer who is perceived to be in accordance with criteria. Then collectors or middlemen deposit or sell the shrimp to the factory for export and some sell it to the local market. The price of shrimp itself fluctuates, depending on the dollar exchange rate and the price on the market. 


\section{Profit and Loss Calculation}

The profit and loss statement shows the state of a business based on the amount of sales, the amount of costs, and the amount of profits earned during one production period. The profit or loss of the shrimp farming can be determined by calculating the difference between the revenue and the expenditure. Based on the calculation, the total revenue of shrimp ponds was $1,415,992,500$ IDR per year. The total cost incurred in one year of production is estimated to be $364,207,148$ IDR. The farmer then earn an income equal to $1,051,785,352$ IDR per year. The net profit of the farmers was the result of the reduction of total revenues with taxes. Based on the calculation result, the farmer net profit annyaly is $999,196,084$ IDR.

\section{Net Present Value (NPV)}

The NPV calculation used the assumption that the value of cash inflows was fixed annually with the economic life of five years and the loan interest rate of $16 \%$, which was derived from the average interest rate from the commercial bank.

The calculation result of the NPV of shrimp farming business in Purworejo Regency is 2,539,407,216 IDR. The value indicates that the investments made for the next five years would earn net benefits assessed currently amounting to 2,539,407,216 IDR, with the value of NPV $>0$ so that the business is feasible to cultivate. It is in line with the statement by Diatin and Kusumawardany (2010) stating that the NPV of vaname shrimp farming business in Indramayu is $7,221,427,150$ IDR so that the business is feasible to cultivate. Internal Rate of Return (IRR)

Based on the calculation done, the IRR value of shrimp farming in the Purworejo District was $98 \%$ and the interest rate was $16 \%$, meaning that IRR $>$ the prevailing interest rate so that the business was profitable and feasible to continue.

\section{Net Benefit/Cost Ratio (Net B/C Ratio)}

The $\mathrm{B} / \mathrm{C}$ ratio value obtained from vaname shrimp farming in the research location was 2.01. The value was greater than 1 so that the farming effort was feasible to cultivate. The value could also be interpreted to mean that each expenditure of $\mathrm{Rp} 1.00$ would get a revenue of 2.01 .

Table 3. shows that with the existence of taxes, it does not affect the feasibility result obtained by vaname shrimp ponds, and show that the business is feasible.

\section{Sensitivity Analysis}

Sensitivity analysis is performed to understand the project which will be designed for changes occurring during investment period. The analysis is done by changing relevant variables with regards 
Table 3. Calculation of NPV, IRR, and Net B/C Ratio

\begin{tabular}{|c|c|c|c|c|}
\hline \multirow{2}{*}{ No. } & \multirow{2}{*}{ Description } & \multicolumn{3}{|c|}{ Year To } \\
\hline & & $\mathbf{0}$ & 1 & 2 \\
\hline 0.16 & Df $(16 \%)$ & 1.0000 & 0.8621 & 0.7432 \\
\hline \multirow[t]{6}{*}{ I } & Inflow (Benefit) & & & \\
\hline & Sales Result & & $1,415,992,500$ & $1,486,792,125$ \\
\hline & Residual Value & & & \\
\hline & Gross Benefit (A) & & $1,415,992,500$ & $1,486,792,125$ \\
\hline & PVGB & & $1,220,727,134$ & $1,104,983,907$ \\
\hline & Total PVGB & & & \\
\hline \multirow[t]{10}{*}{ Ii } & Outflow (Cost) & & & \\
\hline & Initial Investment & $1,033,420,165$ & & \\
\hline & Additional Investment & & $6,106,882$ & $8,607,000$ \\
\hline & Operating Cost & & $351,236,134$ & $368,797,941$ \\
\hline & Tax & & $52,589,268$ & $55,251,159$ \\
\hline & Gross Cost (B) & $1,033,420,165$ & $409,932,283$ & $432,656,099$ \\
\hline & PVGC & $1,033,420,165$ & $353,402,622$ & $321,550,013$ \\
\hline & Total PVGC & & & \\
\hline & Net Benefit (A-B) & $(1,033,420,165)$ & $1,006,060,217$ & $1,054,136,026$ \\
\hline & PVNB & $(1,033,420,165)$ & $867,324,513$ & $783,433,895$ \\
\hline Iii & NPV & $2,539,407,216$ & & \\
\hline Iv & Net B/C & 2.01 & & \\
\hline $\mathrm{V}$ & IRR & $98.65 \%$ & & \\
\hline
\end{tabular}

Source: Primary Data, 2017

Table 4. Sensitivity Analysis of Vaname Shirmp Farming Business

\begin{tabular}{|c|c|c|c|}
\hline $\begin{array}{c}\text { Investment } \\
\text { Criteria }\end{array}$ & $\begin{array}{c}\text { Cost } \\
\text { Rise by } 62 \%\end{array}$ & $\begin{array}{c}\text { Price } \\
\text { Fall by } 30 \%\end{array}$ & $\begin{array}{l}\text { Cost Rise by } 62 \% \text { and } \\
\text { Price Fall by } 30 \%\end{array}$ \\
\hline NPV & $2,250,365,595$ & $1,024,200,131$ & $735,158,509$ \\
\hline Net B/C Ratio & 1.8 & 1.41 & 1.26 \\
\hline IRR & $89 \%$ & $52 \%$ & $42 \%$ \\
\hline
\end{tabular}

Source: Primary Data, 2017

to the business. Thus, the progress of the projects can be monitored in Purrworejo. In vaname fishery business, the adjustment is carried out for production cost and shrimp selling price variable.

Table 4. shows the condition that when the cost rise untill $62 \%$, when the price fell by $30 \%$, there were no change and no effect on the calculated parameters. The sensitivity analysis results obtained in relation with the financial feasibility of the shrimp farming business indicated that it was feasible to cultivate. 


\section{CONCLUSION AND SUGGESTION}

The business of vaname shrimp cultivation in Purworejo District is feasible according to criteria concerning income, NPV, IRR, and Net B/C. The sensitivity analysis in the calculation of financial feasibility indicates no change and no effect on the calculated parameters.

Based on the research, the author's suggestions concerning in the activities of shrimp farming business are (1) workforce training and guidance are given to improve the competitiveness of the farmers, (2) the farmers cooperate with other stakeholders engaged in fisheries, and (3) it is feasible that shrimp farming maintains the existence of vaname shrimp business or expand the business in order to meet market demand.

\section{REFERENCES}

Amri, K., \& Kanna, I. (2008). Budi Daya Udang Vaname Secara Intensif, Semi Intensif, dan Tradisional. Jakarta: PT. Gramedia Pustaka Utama.

Biantara, B., Hartoko, A., \& Purwanti, F. (2016). Analisa Kerentanan Pantai dan Sumberdaya Perikanan dengan Pendekatan SIG di Pantai Kabupaten Purworejo. Maquares, 5(2), 1-10.

Diatin, I., \& Kusumawardany, U. (2010). Analisis Kelayakan Finansial Perluasan Tambak Budidaya Udang Vaname di Cantigi Indramayu. Akuakultur Indonesia, 9(1), 77-83.
Ely, A., \& Darwanto, D. H. (2014). Analisis Kelayakan Usaha dan Strategi Pengembangan Budidaya Rumput Laut di Kabupaten Seram Bagian Barat. Agro Ekonomi, 25(2), 169177.

Geffken, R., Hendrik, \& Zulkarnain. (2017). Business Analysis Of Salted Fish Processing In Pondok Batu Villages Sarudik Subdistrict Sibolga District North Sumatra Province. Online Mahasiswa, 4(1), 1-9.

Lumentut, H. B., \& Hartati, S. (2015). Sistem Pendukung Keputusan untuk Memilih Budidaya Ikan Air Tawar Menggunakan AF-TOPSIS. Computing and Cybernetics Systems, 9(2), 197-206.

Mohani, V. C., Yulianto, E., \& Mawardi, M. K. (2016). Pengaruh Jumlah Produksi Udang Indonesia, Harga Udang Internasional, dan Nilai Tukar Rupiah Terhadap Ekspor Udang Indonesia. Administrasi Bisnis, 39(2), 67-73.

Purnamasari, I., Purnama, D., \& Utami, M. A. F. (2017). Pertumbuhan Udang Vaname (Litopenaeus vannamei) di Tambak Intensif. Enggano, 2(1), 58-67.

Reksono, B., Hamdani, H., \& Yuniarti. (2012). Pengaruh padat penebaran 
Gracilaria sp. Terhadap Pertumbuhan dan Kelangsungan Hidup Ikan Bandeng (Chanos chanos) Pada Budidaya Sistem Polikultur. Perikanan dan Kelautan, 3(3), 4149.

Saputri, K. (2017). Peluang dan Kendala Ekspor Udang Pndonesia ke Pasar Jepang. Ilmu Hubungan Internasional, 5(4), 1179-1194.

Srinivas, D., Venkatrayalu, C., \& Laxmappa, B. (2016). Identifying Diseases Affecting Farmed Litopenaeus vannamei in Different Areas of Nellore District in Andhra Pradesh , India. Fisheries and Aquatic Studies, 4(2), 447-451.

Susilowati, T., Hutabarat, J., Anggoro, S., \& Zainuri, M. (2014). The Improvement of the Survival, Growth and Production of Vaname Shrimp (Litopenaeus vannamei) and Seaweed (Gracilaria verucosa ) based on Polyculture Cultivation. Marine and Aquatic Resource Conservation and Co-existence Research Article, 1(1), 6-11. 